\title{
Design of Organizational Structure and Job Description for Human Capital Management Strategy for Small Medium Enterprise in Creative Industry: RA Planner Company Case
}

\author{
Bagja Auzan Karami and Aurik Gustomo
}

\begin{abstract}
RA Planner is a publisher company that focusing themselves in developing product design to produce a journal and planner. They able to sell 23.000 planner in 2018 and generate almost 2.1 billion rupiah in their 4 years after established. However, the human resources in RA Planner starting to fail keeping up with the rapid growth because their lack of structuration and formal organizational design, resulting their inability to achieve target in 2019. This study uses a mixed method research model, consist of interview to current employee and ex-employee of RA Planner after the decision of firing employee have been made in January 2020 and the conversion of said interview to become quantitative data using BARS methods. Both of this methods are carried out to get the HCM maturity level that consist of 5 dimension that can help determine company maturity state and predict the company performance, and the difference between business process mapping of the company compare to PCF APQC using gap analysis to create RACI Matrix. Then, based on HCM maturity level and RACI Matrix, the author proposes a new organizational structure and job description that can ultimately corresponding with RA Planner need to further answer company strategic initiative and solve the current issues that emerge in the company.
\end{abstract}

Index terms - APQC; HCM Maturity; Organizational Structure; Small Medium Enterprise (SME).

\section{INTRODUCTION}

Creative Industry has been one of the emerging contributors to Indonesia National Gross Domestic Product (GDP), with almost 852 trillion rupiah, or $7,38 \%$ of Indonesia national GDP in 2015, and been forecasted to growth even more to achieve GDP contribution up to $11 \%$ [1]. Out of 16 subsectors of creative industry, publishing subsector begin to show their potential in the recent year with the emerging of new technology and population behavior that heavily depend on such technology, in which the trend of using digital content to write a memo and

Published on October 10, 2020.

Bagja Auzan Karami, Bandung Institute of Technology, Indonesia.

(corresponding e-mail: bagjaauzan21@gmail.com)

Aurik Gustomo, Bandung Institute of Technology, Indonesia.

(e-mail: aurik@sbm-itb.ac.id) reminder began to became a norm among young people, and making the act of writing in physical journal book as an oldschool activities. Those label doesn't affect the fact that physical journal and planner was still popular to be use by young adult and adult alike to help them organize their work, but instead helping to form a new mindset in today youth's toward mundane activity such as writing a journal as nostalgia trip and 'hype' by youth that like old-school theme, and changing the perspective of journal and planner from a practical item, to novelty item that appealing to be own and use.

RA Planner is a publisher company that focusing themselves in developing product design to produce a journal and planner. They able to sell 23.000 planner in 2018 and generate almost 2.1 billion rupiah in their 4 years after established. However, the human resources in RA Planner starting to fail keeping up with the rapid growth because their lack of structuration and formal organizational design, resulting their inability to achieve target of 3.2 billion using only Annual Agenda Book edition 2020, which is 1.5 times bigger that previous year. But at the end, RA Planner able to achieve those targets by adding the sales of the other product in their portfolio [2]. After that incident, there begin to spring up an issue between employee and manager. Some of the issues was employee inability to see manager as their supervisor and seeing them as nothing but a friend, employee begin to talk behind manager back and continuedly creating baseless rumor, then ending up creating unhealthy relationship between the two. Because of this, The CEO decide to fire every single employee other than original manager. This problem occur because the company doesn't have any organizational structure nor job description, resulting employee unable to perform as intended simple because they only do the task that they been ordered to do at the time, but not the task that their position intend to do.

\section{LITERATURE REVIEW}

\section{A. Human Capital Management Maturity}

The Human Capital Maturity Model [3] is an assessment model that consist of five stage of HCM maturity level degree from nonexciting, poor, adequate, superior, and excellence. The HCM maturity itself is consist of 5 dimensions, namely Leadership, Employee Engagement, Knowledge Accessibility, Workforce Optimization, and Learning Capacity. Every dimension has their own unique 
indicator to further help us to determine the level of each dimension. Take the sum of the five subtotals from the sections above (note that the sections with five categories are multiplied by 0.8 in order to weight them equally with the sections that have four categories),

\section{B. Business process Mapping}

The value-chain analysis is an analysis tools that try to break down organization activities in all the sequential process that they do to create value or adding value [4]. RA Planner current business process can be breakdown to few levels based on company current value chain:

TABLE 1: EXISTING BUSINESS PROCESS

\begin{tabular}{|c|c|c|c|}
\hline \multicolumn{4}{|c|}{ Existing Business Process } \\
\hline Level 0 & Level 1 & Level 2 & Level 3 \\
\hline \multirow{3}{*}{ Order } & \multirow{3}{*}{ Receiving order } & \multirow{3}{*}{ Order verification } & Recording order and information detail for each purchase \\
\hline & & & Confirming the type of product and the design that the customer order \\
\hline & & & Confirmation for the payment of the total purchase \\
\hline \multirow{17}{*}{ Production } & \multirow{10}{*}{$\begin{array}{l}\text { Preparation for } \\
\text { production }\end{array}$} & $\begin{array}{l}\text { Calling the printing } \\
\text { company }\end{array}$ & $\begin{array}{l}\text { Making an appointment to with the printing company, in this case PT. } \\
\text { Gramedia Asri Media }\end{array}$ \\
\hline & & \multirow{3}{*}{ Negotiation } & Negotiation regarding price \\
\hline & & & Negotiation regarding the quality of the material to use \\
\hline & & & Negotiation regarding the total of production for each item \\
\hline & & \multirow[t]{2}{*}{ Material checking } & $\begin{array}{l}\text { Checking the condition of the material that will be use for the } \\
\text { production }\end{array}$ \\
\hline & & & Checking the quantity of the material that order for the production \\
\hline & & \multirow{4}{*}{$\begin{array}{l}\text { Verification or } \\
\text { production order }\end{array}$} & Confirming the verification from the director \\
\hline & & & Confirming the detail of production order \\
\hline & & & Do the payment \\
\hline & & & Receiving invoice order from printing company \\
\hline & \multirow{7}{*}{ Production process } & \multirow{3}{*}{ Quality control } & $\begin{array}{l}\text { Quality control using random sampling for each product line that have } \\
\text { been created }\end{array}$ \\
\hline & & & Revision if necessary, before the full production begin \\
\hline & & & Confirming the full production process with the printing company \\
\hline & & \multirow{4}{*}{ Storage } & Preparing the warehouse \\
\hline & & & Accepting delivery from the printing company \\
\hline & & & Checking the order and quality of the product upon delivery \\
\hline & & & Storage the product \\
\hline \multirow{9}{*}{ Delivery } & \multirow{2}{*}{ Confirming order } & \multirow{2}{*}{$\begin{array}{l}\text { Confirming purchases } \\
\text { and payment }\end{array}$} & Payment verification \\
\hline & & & confirm the payment deferment for the reseller \\
\hline & \multirow{3}{*}{ Packaging } & \multirow{3}{*}{ Packaging } & Divide the product for delivery based on province and city \\
\hline & & & Verify the customer information detail and address \\
\hline & & & Packaging the product using wrapper \\
\hline & \multirow{4}{*}{ delivery } & \multirow{4}{*}{ Delivery } & Contacting delivery partner, in this case JNE \\
\hline & & & Dropping the product to JNE \\
\hline & & & Receiving the invoice from delivery company \\
\hline & & & Delivery the product \\
\hline
\end{tabular}

\section{GAP Analysis}

Gap analysis is used to develop the quality of a job to produce the best product or service, therefore to get the best results, the work activities used in the gap analysis process must be more advanced and developed than the existing work that being compared to [5] so that the analyzed process experiences quality development and produces the best process [6]. The difference between current business process mapping of the company compare to PCF APQC version 721 will be analyses using gap analysis to create RACI Matrix, therefore capturing the real condition of whether the work performed is as expected or not.

\section{RACI Matrix}

The RACI matrix is an acronym that derives of Responsibility, Accountable, Consulted, and Informed, in which every one of them is four different types of roles that are considered. [7]

\section{E. BARS Method}

BARS is a performance appraisal method that aims at combining critical incidents and ratings (quantified ratings) by using a scale that draws specifically about good and bad performance [8]. To achieve more objective rating for the necessary BARS, author will be using Focus Group
Discussion (FGD). FGD is a data collection technique generally done in qualitative research with the aim of finding meaning a theme according to the understanding of a group.

The FGDs was conducted at 13 February 2020, with 4 people as the participants that are consist of 3 manager and 1 director of the company that have been working at RA Planner from the first time the company had been established. The FGDs in this research is used to create concreate and objective description of each level that consist from level 1 to 5 for each indicator in HCM Maturity of the company that based on 5 HCM maturity level by Bassi and McMurren [3].

\section{F. Internal Factor Analysis}

RA Planner internal analysis was carried out using SWOT Analysis. SWOT Analysis is an analysis that is based on logic that can maximize strengths and opportunities, but simultaneously can minimize weaknesses and threats [9]. RA Planner SWOT analyses can be summarizing as: 


STERNGTH
1. Based on interview and observation, RA
Planner are pioneer of personalized annual
agenda book in Indonesia
2. Good quality product with thick cover, full
color, and use ring as the edge of book
3. Every product was provided in 5 different
variation to increase variability
4. Cheaper price compares to competitor
5. Strong reseller program in Java
6. Reseller willing to fund the marketing
themselves
7. Have media presences, especially in Islamic

WEAKNESS

1. The employees mostly college student or college graduate without experience Job structure or company business process was vague

3. Doesn't have reseller outside of Java

4. Other product was much more forg Other product was much more forge
compare to Annual Agenda Book Restrict itself to cater Islamic communities because of the Islamic value that they adopt 6. Only using Instagram as marketing tools

Their product wasn't available at local 7. Their product wasn't available at
bookstore (Gramedia, Togamas, etc.)

\begin{tabular}{|c|c|}
\hline $\begin{array}{l}\text { OPPORTUNITIES } \\
\text { 1. Support from the government, in term of } \\
\text { recommendation for e-commerce as the } \\
\text { marketplace for the creative industry } \\
\text { 2. Caterer millennials taste and need } \\
\text { 3. Cited and sources from reputable news } \\
\text { portal or website } \\
\text { 4. The increase of online purchases in today } \\
\text { climate } \\
\text { 5. Emerging of social media influencer as } \\
\text { marketing tools for their followers that have } \\
\text { high engagement }\end{array}$ & $\begin{array}{l}\text { THREATS } \\
\text { 1. New competitor began to emerge } \\
\text { 2. Some of the new competitor was household } \\
\text { name with big following and have strong } \\
\text { engagement with their followers, that's } \\
\text { include social media influencer and } \\
\text { celebrities } \\
\text { 3. Some application and software become } \\
\text { substitute product }\end{array}$ \\
\hline
\end{tabular}

Fig. 1 SWOT Analysis of RA Planner

\section{G. External Factor Analysis}

External analysis aims to determine the opportunities and threats in the macro environment, industrial and competitive that occur in a company. RA Planner external analysis was carried out using PEST Analysis and Porter's Five Forces.

PEST Analysis is a method to explain environmental condition information. This also provides a framework for summing up the external environment of company operations. The business must comply with four factors, such as political, economic, socio-cultural, and technological [10]. Through this method, the industry scope that will be analyzed are personalized journal or planner in creative industry and in publishing subsector.

At the moment, Badan Ekonomi Kreatif (Bekraf) are the sole political group that officially been assign by Indonesia Government, with the responsible to managing and governing all aspect in creative industry to create conducive environment for creative industry ecosystem, giving guidance and support in technical and managerial for all players in creative industry, creating policy for the advancement of creative industry, and coordinating with other institution in Indonesia Government to further support the industry [11]. Sadly, after Covid-19 hitting the world in early March, almost all of GDP forecast growth around the world was shattered and creating one of the poorest performances of GRP growth in Indonesia. Badan Pusat Statistik (BPS) stated that economic growth in I quarter/2020 only setting in $2,91 \%$, becoming Indonesia worse economic growth since the last two decade, specifically since 2001. If we even compare this quarter economic growth with IV quarter/quarter, that the economic growth of Indonesia was actually minus 2,41\% [12]. Because of these negative growths, it will be indicating lower purchasing power from Indonesia population, and making them prioritize purchasing necessary and essential goods rather than novelty item. At the moment the rapid growth of technology advancement is already giving a lot of impact in almost every aspect of human life. According to Kemp in We Are Social article [13], from total of 268,2 million population in Indonesia, $133 \%$ of them, or 355,5 million people have a mobile subscription, and almost half of them use their smartphone to access internet, especially to access social media. With those number of active internet user, the player in creative industry can use it as their advantages by implementing business strategy according to public trends that can be easily gathered using social media. At the other hand, technology actually bringing harm to creative industry, especially to literature-based subsector that heavily rely on consumers behavior in consuming a physical goods, such as reading book or writing. Those harm was emerging long side of tech based industry that begin to transfer almost every physical activities to digital activities, decreasing the change of new potential buyers to try buying a journal based product in the shape of a book, and prefer to just download an apps that can do the exact same function as the physical one

The five forces model allows strategic leaders to analyze all players using a wider industry lens, which in turn enables a deeper understanding of an industry's profit potential. Moreover, a five forces analysis provides the basis for how a firm should position itself to gain and sustain a competitive advantage [14]. The summary of Porter's Five Forces analysis of industry analysis are as follows:

\section{a) Threat of New Entrants: Low}

If someone want to begin their journey in creative industry subsector creative design that mainly creating a planner or journal, they must prepare capital that includes the purchase of printing equipment, raw materials, and advertising needs. Even though the company doesn't have a printing tool, they can cooperate with other printing company so that it can reduce the capital burden, but usually, before a third party printing company began to produce your product, they will set a minimum amount of printing in each session for each product, and usually the minimum amount they ask before they can produce are in the thousands. A cheaper option indeed rather than buying new equipment, but not cheap enough to making it easy to do. Therefore, this can be classified according to the definition the threat of new entrants in the journal product are categorized as low

\section{b) Threat of The Substitutes: High}

Substitute product are goods or services from outside a given industry that perform similar or the same functions as a product that the industry produces [15]. A journal or planner in any kind of shape are began to circulate in the market with their own twist and unique identity, especially in the shape of mobile based applications that have the same function as journal or planner, such as Google Calendar, Pregnancy+, Day One, Diarium, Excel etc. Because of this, there is wide variety of application or software that can be a substitute to all the product

\section{c) Bargaining Power of Suppliers: High}

In creative industry, especially in sub sector of product design, printing company can become one of the most important players in the industry, especially for a company that doesn't have their own printing equipment, such a case is RA Planner. the requirement that RA Planner need for their printing partner can make good quality product while still maintaining cheap price. All the product that RA Planner have is print in Bandung, and in Bandung, there are two large printing presses that can be partner with, which 
PT. Gramedia Asri Media and PT Granesia. At the end, RA Planner build a partnership with PT Gramedia Asri Media because they able to fulfil the requirement that they needed.

There are more than 50 publishers in Bandung, and most of them have the same condition with RA Planner, in which they don't have their own printing equipment, making them much more depended to suppliers, in this case printing company. Because of this, two printing company that mostly become their main choice to be partner with, have a much more control to set a price for a production, making the publisher enable to gain bigger profit. Based on that, we can conclude that the power of suppliers in journal and planner product are high.

\section{d) Bargaining Power of Buyers: Medium}

According to Rothaermel [14], the power of buyers is high when:

1) There are a few buyers

Everyone can use a journal or planner, but sadly not everyone wants to use it. Customers can easily change their purchasing decisions of buying a journal or planner because not everyone is persistent enough to write all the details of the activity or all the planning that they have in a book.

2) The industry's product is standardized or undifferentiated commodities

In principal, all products offered by RA Planner and other publisher in journal or planner industry are essentially a same product, in which people use the product to write and record certain information and plan in a journal. However, each product has their own personality and uniqueness that make their product different than others, such as:

- Not every journal are yearly agenda or scheduling tools, some journal or planner can be developed to be difference type that can cater specific need, such as a financial planner for people that need financial planning in their daily life, or a baby journal that specifically use by pregnant mother and mothers with infant to record their child development.

- Difference format of content for each type of journal that doesn't following a certain standardized system, making every journal or planner unique

- Different design and color that differentiate them with other

3) Buyers face low or no switching costs

Customers can buy other product without have to worry about switching costs, thus, if a journal or planner have higher price or poor design, customers can easily move to competitors.

\section{e) Rivalry among Competitors: High}

The existing company in personalized journal and planner market is indeed creating their own unique product to attract more customers, creating diverse option to choose for the potential customers, making it harder for a certain product to stand out. The most troublesome competitors in this industry came in the form of social media influencer or a major celebrity that began to utilize their fame as an influencer to advertise their own journal or planner to their wide audience. Because of their high engagement with their followers in social media, they able to facilitate easier way to advertise their product.

\section{RESEARCH METHODOLOGY}

The conceptual framework used in this study is consist of 3 steps. The first one, preliminary data, was to conduct business issues exploration using interview and observation, then analyze them to identify the root cause. Secondly, after gathering the necessary data, the author begin to do an organizational assessment that consist of 3 aspect, namely Human Capital Maturity to capturing the weakness in HCM maturity drivers, analyzing business process mapping using gap analyzes using existing business process and PCF APQC version 721 of strategic initiative plan that management have, mainly their intent to build or buy a printing factory and creating new unit that focused on developing new product, and the development of strategic formulation using SWOT, PEST analysis, and Porter's 5 Force Industry Analysis. Using the 3 aspect, which is Human Capital Maturity, business process mapping, and strategic formulation, then the new strategic plan can be proposed, in this case the proposed strategic was to create organizational structure and job description. Lastly, in the third step, the conclusion can be formulated, and the implementation plan can be introduced. The Conceptual framework used for this research shown in Fig. 2.

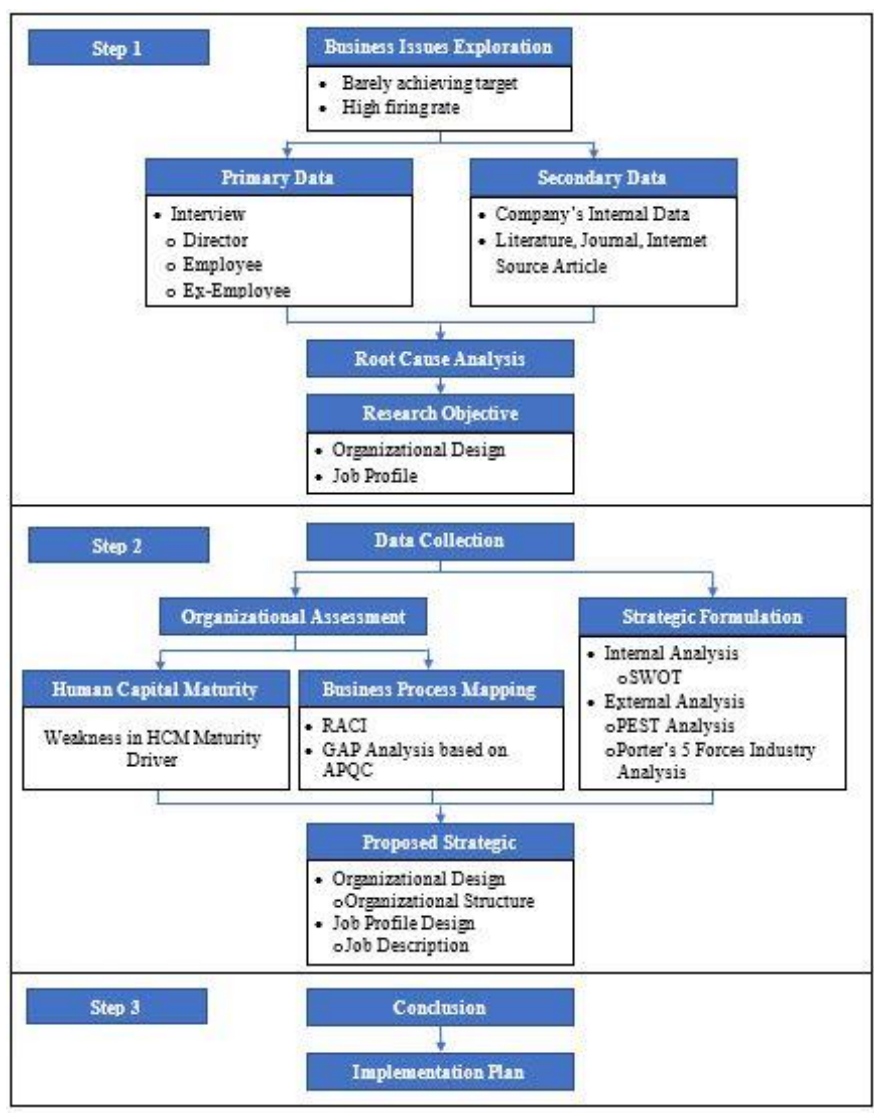

Fig. 2 Conceptual Framework.

\section{FINDING AND ARGUMENT}

Based on HCM maturity level, the result show that knowledge accessibility are the lowest dimenstion with mean value of 10.14 , and 2 dimension that have the lowest mean value, namely availability and collaboration, with mean value of 1,00 and 2,71 respectively. This mean that the employee feels and assess that the company either fail or 
never provide a necessary information regarding any training module that they can use to improving their capabilities, and the employee felt that for the most part, managerial rarely asking them to solve a problem via teamwork

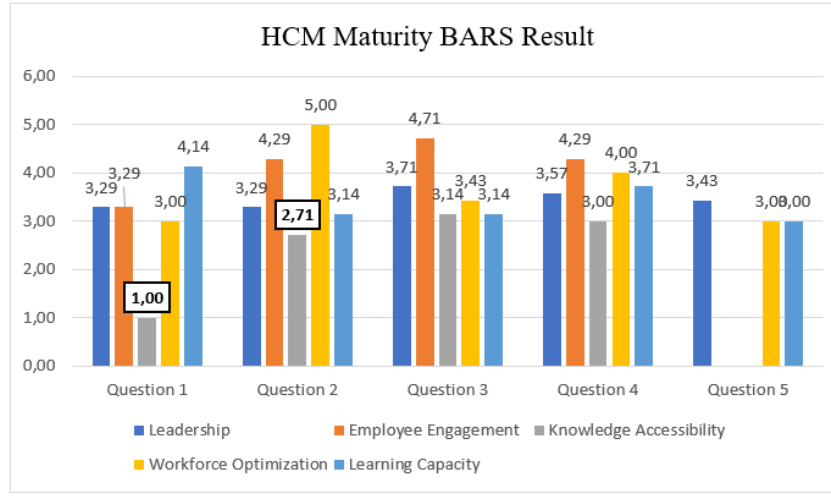

Fig. 3. HCM Maturity Dimension BARS Result.

The result of GAP analyzes can be seen through RACI Matrix in Table 2.

TABLE 2: RESULT OF RACI MATRIX FOR EACH UNIT

\begin{tabular}{|c|c|c|c|c|c|}
\hline Role & CEO & $\begin{array}{c}\text { Creative } \\
\text { Product } \\
\text { Development }\end{array}$ & $\begin{array}{c}\text { Funance, HR, } \\
\& \text { General } \\
\text { Affair }\end{array}$ & $\begin{array}{c}\text { Sales and } \\
\text { Marketing } \\
\text { Unit }\end{array}$ & $\begin{array}{c}\text { Production } \\
\text { Unit }\end{array}$ \\
\hline R & 11 & 7 & 28 & 21 & 15 \\
\hline A & 24 & 0 & 25 & 16 & 15 \\
\hline C & 13 & 3 & 36 & 23 & 18 \\
\hline I & 53 & 71 & 38 & 49 & 60 \\
\hline
\end{tabular}

Based on the current size of the company before the firing almost more than half of their employee, RA Planner is a small enterprise without any work unit, and only consist of one employee that represent one major task, but at the same time still given work outside of their initial task. To devise the suitable organizational structure of the company, the proposed organizational structure will be create based on 3 aspect that need to be considered, that aspect is consist of HCM Maturity level, the GAP analysis between existing and proposed business process mapping, and company strategic initiative that include all the managerial intent for the future of the company

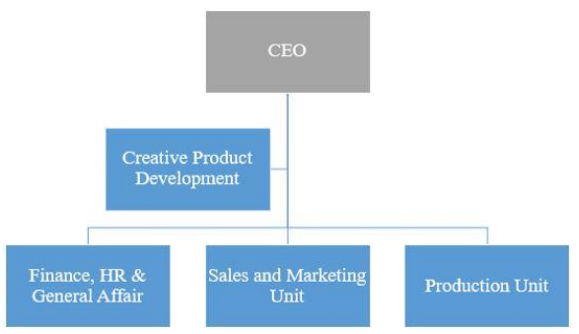

Fig. 4. Proposed Organizational Structure.

The proposed organizational structure was consisting of 4 layers, in which the Board of Director at the highest level with the task to creating a planning and policy decision, such as setting organizational direction (mission, vision, goals, and objectives), responsible for funding the planning and policy decisions, and monitoring the implementation of the planning and policy decision while providing sanction. At the second layer, there are CEO (Chief Executive Officer) that will be received direct instruction from the Board of Director. At RA Planner, CEO primary responsibilities include making major corporate decisions, managing the overall operations and resources of a company, acting as the main point of communication between the Board of Director and corporate operations Other than that, CEO will be doubles as Creative Director, in which they will monitoring brand campaigns, revising presentations, and shaping brand standards along with the Creative Product Development.

CEO will overseer and provides instruction to 4 others unit, namely Research \& Development Unit, Finance, HR, \& General Affair, Sales and Marketing Unit, and Production Unit. The Research \& Development Unit will have main responsibility in creating the overall design, visual style, and develop the artwork or the layout of the product, and creates engaging content that is disseminated across various product, and generating the content of the product, words, and slogans that accompany advertising visuals. The Finance, HR, \& General Affair are directly responsible for the overall administration, coordination, and evaluation of the financial status of the company, the human resource function in the company and all general affairs regarding to the company. The third unit is Sales and Marketing Manager, that responsible for researching and developing marketing opportunities and planning and implementing new sales plans. The Sales and Marketing Manager will also manage both the marketing and the sales staff and will perform managerial duties to meet the company's operations goals, while maintenance partnership with registries reseller. The last unit is Production Unit, they mainly responsibility is for the technical management, supervision and control of industrial production processes, while still oversee the efficient receipt, storage and dispatch of a range of product from company warehouse.

\section{CONCLUSIONS}

Unstructured and unclear organizational structure and any job-related information of each position can affect the effectiveness of the productivity in RA Planner, which have been prove by the company inability to achieve the 2019 target revenue. It was proven in HCM Maturity Level, in which RA Planner actually already able to show adequacy or baseline, capabilities that form a good foundation for improvement in the area of HCM factors mentioned, but in the Knowledge Accessibility Dimension, not only they show a poor result, one of the indicator, namely availability get the lowest possible score, which is 1,00 , proven the fact that the company doesn't any job-related information. To solve the problem that RA Planner currently facing and preparing them to support their strategic initiative of purchasing a printing factory, author intended strategy is to formulate a new organizational structure and job description for the company

\section{REFERENCES}

[1] Badan Ekonomi Kreatif Indonesia. (2019). Opus. Creative Industry Outlook.

[2] RA Planner. (2020). Corporate Internal data. Bandung: RA Planner Bookstore.

[3] Bassi, L., \& McMurrer, D. (2007). Maximizing Your Return on People. Harvard Business Review. Harvard Business Review. 
[4] Dess, G. e. (2013.). Strategic Management: Text and cases Seventh Edition. New York.

[5] Maulana, A., \& Susilo, D. (2014). Pengurangan Aktivitas Pada Prosess Bisnis Untuk Memperpendek Lead Time Pada Proses Service. Jurnal Ilmu Manajemen.

[6] Astrofah, T., Zailani, S., \& Fernando, T. (2010). Best Practices for the Effectiveness of Benchmarking in the Indonesian Manufacturing Companies.

[7] Khan, P., \& Kaleem, A. (2014). Impact of RACI on Delivery \& Outcome of Software Development Projects. Fourth International Conference on Advanced Computing \& Communication Technologies.

[8] Dessler, G. (2015). Manajemen Sumber Daya Manusia. Jakarta: Salemba.

[9] Rangkuti, F. (2013). Analisis SWOT Teknik Membedah Kasus Bisnis. Jakarta: Gramedia Pustaka Utama.

[10] Hunger, J., \& Wheelen, T. (2015). Strategic Management and Business Policy. 14th Edition. New York: Pearson Education Inc.

[11] Bekraf. (2020). Tugas Bekraf. Retrieved from BEKRAF: https://www.bekraf.go.id/profil/tugas

[12] Ekonomi Bisnis.com. (2020, 05 05). Gara-Gara Corona Pertumbuhan Ekonomi Indonesia Terendah dalam 2 Dekade. Retrieved from Ekonomi https://ekonomi.bisnis.com/read/20200505/9/1236576/gara-garacorona-pertumbuhan-ekonomi-indonesia-terendah-dalam-2-dekade

[13] Kemp, S. (2020, 01 30). Digital 2020: 3.8 Billion People Use Social Media. Retrieved from We are Social: http://www.wearesocial.com

[14] Rothaermel, F. (2017). Strategic Management (3rd Edition). New York: McGraw-Hill Education.

[15] Hitt, M. A., Ireland, R. D., \& Hoskisson, R. R. (2011). Concepts Strategic Management Competitiveness \& Globalization (9th Edition). USA: South-Western Cengage Learning.

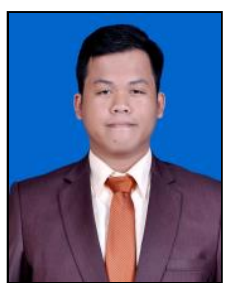

Bagja Auzan Karami, S. Psi. was graduated from Universitas Islam Bandung in 2017 majoring in Psychology Studies. He continues his postgraduate education in Business Administration at Bandung Institue of Technology, Indonesia. He focused on the concentration of human capital management and Geenral Management. His working experience in an internship at PT. Bersama Zatta Jaya, or widely known as Elcorps as Human Resource division in 2019.

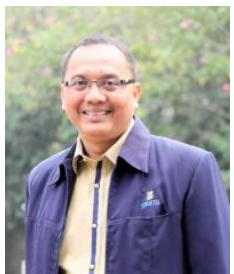

Prof. Dr. Aurik Gustomo, S. T., M. T., is a Professor of People Development. He earned his doctoral degree at Doctor of Business Management, IPB University (2012), holds the degrees of master's in engineering from Industrial Engineering \& Management, Bandung Institute of Technology (1999), and Bachelor of Engineering from Industrial Engineering, Bandung Institute of Technology (1996). He became a lecturer in Industrial Engineering Department of ITB in 1996 and have been joining SBM-ITB since 2003. He was also one of the founders of SBM-ITB. After being the Vice Dean of Resources in 2013 - 2020, he is now the Vice Dean of Academics affairs 